セッション 8-7

\title{
メディカルフィットネスシステム 一パソコンネットワークシステム上での開発一
}

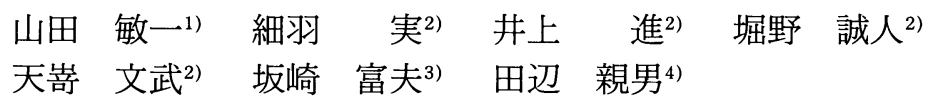

\section{目的}

会員数 500 名のメンバーズクラブで会員の健康増進 のために，汎用コンピュータ上で利用してきたメディ カルフィットネスシステムを柔軟で拡張性に富み, 経 済性が高いパソコンネットワークシステムにリプレイ スした。この新システムについて報告する。

\section{方 法}

フィットネスの定義自体が非常に曖昧であるが, 運 動を行うことにより体力を増し，ストレスを解消し， 病気の予防を行うことである。医学的情報, 個人の健 康情報を取り入れたフィットネスシステムをメディカ ル・フィットネスと呼んでいる。

このメディカル・フィットネスをコンピュータシス テム化して次のように活用してきた。

1）健康診断,体力測定の結果をオンラインでコンピ ユータに取込み, その結果を解析して最適なトレーニ ングメニューを自動作成する。それに従ってトレーニ ングを行うことにより, フィットネスクラブ会員の健 康体力増進を図る。

2）会員の健康診断により得られる健康情報を経時 的にコンピュータに集積し，これをもとに，様々な指 導・情報提供を行い健康増進に役立てる。

3）コンピュータに集積された情報をクラブの事 務・管理業務効率向上のため, 多方面に活用する。

メディカルフィットネスシステムは汎用コンピュー 夕上で健診システムの一部として設定していたが，今 回, パソコンネットワーク化にあたり, 独立したシス テムとして設計を行った。

パソコンはインテル系 CPU, DOS/V下で作動する Windows (マイクロソフト社製)，ネットワーク環境と

\section{Medical Fitness Systems, Which are Developed in a} Network System Usinig a Personal Computer

1）島津製作所 情報システム部

2）島津製作所 医用事業部

3）坂崎診療所

4）京都メディカルクラブ 500
して Ethernet, Netware（ノベル社製）を採用した。 パソコンネットワークはサーバーパソコン 1 台と複数 のクライアントパソコン，それらを接続する Ethernet より構成され，データベースはネットワーク OS であ る Netwareにより一元管理される。

また, 開発に当たり, 単にパソコンネットワーク化 するだけでなく, 同時に次のような項目について機能 追加抢よび改善を行った。

1）各施設の既設健診システムの健診データを取り 込めるようにした。これにより，過去の健診データの 蓄積を生かすことができる。

2) 健康診断, 体力測定の結果を解析して最適なトレ ーニングメニューを自動作成する時, 判定項目として 診断名を必要としていたが, 所見でも可能とした。ま た, 既往歷, 問診等も判定項目に追加し, 作成メニュ 一の精度を向上させた。

3）トレーニング機器をグループ分けして, 指定グル ープごとに, 最適メニューを自動作成できるようにし た。これにより，トレーニング機器を限定したメニュ 一作成ができる。

4）クラブ会員の個人情報管理項目を大幅に増やし, 検索機能を強化した。これにより, クラブ会員へのサ ービスがよりきめ細かくできるようになる。

5）ビジターの個人情報管理もクラブ会員に準ずる ようにした。これにより，会員となった場合の情報移 行が可能となる。

\section{結 論}

パソコンネットワーク化によって, 導入コスト・ラ ンニングコストの低減, 施設の規模による順次システ ム構成を拡大できる拡張性, そして, ユーザーインタ ーフェースに優れた画面設計の採用が可能となった。

また， 5 項目に渡る機能追加および改善により，シ ステムの完成度を高めることができた。

今後は, トレーニングメニュー自動作成機能につい て, 現場の利用実績をフィードバックして改良を重ね る予定である。 